\title{
Determination of Fusarium Species Associated with Onion Plants (Allium cepa) in Field in Burkina Faso Causing Damping-Off and Bulb Rots
}

\author{
Konwende Raïssa Kintega ${ }^{1,2 *}$, P. Elisabeth Zida1, Romain Soalla1, Vianney W. Tarpaga1, \\ Philippe Sankara ${ }^{2}$, Paco Sereme ${ }^{1}$
}

${ }^{1}$ Laboratoire de phytopathologie Institute de l'Environnement et de Recherches Agricoles (INERA), Ouagadougou, Burkina Faso ${ }^{2}$ UniversitéJoseph Ki-ZERBO, Ouagadougou, Burkina Faso

Email: *kintegarassa@yahoo.fr

How to cite this paper: Kintega, K.R., Zida, P.E., Soalla, R., Tarpaga, V.W., Sankara, P. and Sereme, P. (2020) Determination of Fusarium Species Associated with Onion Plants (Allium cepa) in Field in Burkina Faso Causing Damping-Off and Bulb Rots. American Journal of Plant Sciences, 11, 64-79.

https://doi.org/10.4236/ajps.2020.111006

Received: December 16, 2019

Accepted: January 14, 2020

Published: January 17, 2020

Copyright $\odot 2020$ by author(s) and Scientific Research Publishing Inc. This work is licensed under the Creative Commons Attribution International License (CC BY 4.0).

http://creativecommons.org/licenses/by/4.0/

\begin{abstract}
Onion (Allium cepa L.) is the second most important vegetable crop in Burkina Faso and provides an important source of income for those involved in the sector. However, producers are facing significant pre-harvest and post-harvest losses. To date, knowledge of major diseases of the crop is limited, limiting the development of effective control strategies. The objective of this study was to test the pathogenicity of some species of Fusarium. To this end, 33 fungal isolates collected from onion plants in 17 localities and belonging to five Fusarium species were used to inoculate onion seeds and bulbs to determine the pathogenic species responsible for damping-off on seedlings and basal bulb rot in Burkina Faso. The virulence of pathogenic isolates was determined according to the percentages of seedling damping-off evaluated 28 Days After Sowing, and the extent of rot in millimetres on inoculated bulbs. The evaluation of isolates on seedlings revealed that the most pathogenic isolates belong to the species $F$. proliferatum (I29, I21, I37, I33, I31), F. thapsinum (I35) and F. sola$n i$ (I38) which resulted in $58.33 \%-70.83 \%$ of seedling damping-off. The most pathogenic isolates on bulbs belong to the species $F$. proliferatum (I4, I29, I32) and F. oxysporum (I52, I50, I16) which caused 21.67 to $25 \mathrm{~mm}$ of rot on bulbs. Isolate I29 was very virulent on both seedlings and bulbs. The isolates of $F$. fujikuroi species were all low pathogenic on seedlings but one of them, (I27), expressed average pathogenicity on bulbs.
\end{abstract}

\section{Keywords}

Fungal Pathogen, Violet de Galmi, Fusarium, Seedling Damping-Off, Bulb Rots 


\section{Introduction}

In Burkina Faso, agriculture is the main source of income for the poorest populations and the basis for the country's food security. It employs more than $80 \%$ of the population and contributes about 33\% to the Gross Domestic Product (GDP) [1]. The State of Burkina Faso, through the Ministry of Agriculture and Hydro-Agricultural Facilities (Ministère de l'Agriculture et des Aménagements Hydro-agricoles) and its partners, are building dams and water reservoirs to promote off-season crops. These crops make a substantial contribution to the fight against food insecurity. Onion (Allium cepa L.) is one of the main vegetable crops in West Africa and more particularly in Burkina Faso where they were introduced around 1915-1920 [2]. In Africa, onion production is very low and does not cover demand [3]. This production deficit, particularly in West Africa, makes this sub-region an import zone for fresh onion from developed countries such as the Netherlands and France. The crop yield varies from country to country, ranging from $20 \mathrm{~T} /$ ha in Burkina Faso, Togo and Senegal to $35 \mathrm{~T} / \mathrm{ha}$ in Niger [4]. The average onion yield in this area is estimated at less than $20 \mathrm{~T} / \mathrm{ha}$ compared to 40 to $60 \mathrm{~T} / \mathrm{ha}$ in the United States and the Netherlands [5]. This low yield recorded in Africa is mainly due to biotic constraints [6] [7]. Fungal diseases occupy a prominent place among bio-aggressors [8]. Of these diseases, onion basal rot or Fusarium head blight is recognized as one of the most harmful onion diseases with a damage rate of more than 50\% [9] [10] [11] [12]. The disease begins in the field and presents symptoms such as delayed emergence, pre-emergence and post-emergence damping-off, late growth, chlorotic leaves, necrosis, root and bulb discoloration, rot and death of the plant [13]. These effects continue in the post-harvest stage and cause losses in the quantity and quality of bulbs in storage [13] [14] [15]. Among the different Fusarium species recognized as basal onion rot agents in the world, F. oxysporum, F. solani and $F$. proliferatum are the most frequent species, among which $F$. proliferatum [12] [16] [17] and F. solani have the capacity to produce mycotoxins [18]. The extent of damage caused by Fusarium species varies not only with the cultivar but also with the type of isolate [10] [19] [20]. In Burkina Faso, several cases of fungal attacks causing significant damage to onion cultivation have previously been reported; however, formal identification of these pathogens has not been done [21] [22]. The findings of Dabiré revealed that seedling damping-off, Fusarium rot, black mould, leaf spot disease, purple spot disease, pink root disease and white rot are the main fungal diseases of onion in Burkina Faso [23]. In view of damage caused by these diseases, a better understanding of the most pathogenic species is needed; and the objective of this study was to test the pathogenicity of 33 Fusarium isolates belonging to five species (F. oxysporum; F. thapsinum; $F$. proliferatum; F. solani and F. fujikuroi) isolated from onion plants in Burkina Faso, in order to determine the species involved in seedling damping-off and onion bulb rot for the development of an appropriate and sustainable management method for these pathogens. 


\section{Material and Methods}

\subsection{Pathogenicity Assessment of 33 Isolates of Different Fusarium Species on Onion Seedlings}

The pathogenicity of 33 monospore isolates of Fusarium belonging to five species: Fusarium oxysporum (13 isolates); Fusarium proliferatum (15 isolates); Fusarium solani (2 isolates); Fusarium fujikuroi (2 isolates); Fusarium thapsinum ( 1 isolate), was assessed on onion seedlings. These isolates were collected from onion plants from 17 production sites in Burkina Faso: Yako, Ouahigouya, Titao, Korsimoro, Kongoussi, Mogtédo, Loumbila, Donsin, Kokologho, Koudougou, Réo, Gnassan, Di, Tougan, Dano, Soumasso and Bama (Figure 1) and identified using molecular technology [24].

Seeds of the "Violet de Galmi" (Safari) variety, originating from Niger and widely grown in Burkina Faso, were purchased commercially and used in the study. Pathogenic isolates were determined under greenhouse conditions (between $25^{\circ} \mathrm{C}$ and $28^{\circ} \mathrm{C}$ ), based on the percentages of pre-emergence and post-emergence seeding damping-off evaluated at 12 and 28 days after sowing. The seeds were disinfected using $70 \%$ alcohol for 30 seconds, then with sodium hypochlorite at $3 \%$ for 3 minutes. For each isolate, a conidial suspension of $10^{6}$ spores/ml concentration was prepared from a 10-day-old culture and $25 \mu \mathrm{l}$ of this suspension was placed on each onion seed at planting, just before closing the hole. Twenty-four onion seeds were used per isolate. Seeds inoculated with sterile distilled water were used as a control. The study was conducted following a randomized complete block design consisting of 34 treatments (33 isolates + control) and 6 replications using one bulb per replication. Seeding was carried out in plastic blister packs containing Jarditropic soil, (multi-purpose soil composed of black peat, blond peat, pine bark and fertilizer) previously sterilized. The data were analyzed using the Statistical Analysis System (SAS) software, version $8 ; 2001$. Isolate means separation was performed according to Duncan's test, at the $5 \%$ significance level. Based on the percentages of seedling damping-off (pre-emergence and post-emergence damping-off), the isolates were grouped into three classes using the grouping method proposed by Sassaki [25] with a slight modification: highly pathogenic (seeding rate $>50 \%$ ), moderately pathogenic (rate between $20 \%$ and $50 \%$ ) and low pathogenic (rate $<20 \%$ ).

\subsection{Pathogenicity Assessment of 33 Isolates of Different Fusarium Species on Onion Bulbs}

All the 33 isolates previously tested on seedlings were also used to assess the pathogenicity on onion bulbs using the methodology described by Bayraktar and Dolar [26]. The bulbs of the "Violet de Galmi" variety, bought at the market, were previously cleaned of external scales and roots, and then disinfected with $70 \%$ alcohol for 30 seconds. A hole of $4 \mathrm{~mm}$ in diameter and approximately 5 $\mathrm{mm}$ deep was made on the basal stem of each bulb using a punch. Thereafter, for each isolate, $10 \mu \mathrm{l}$ of conidial suspension of $10^{6}$ spores $/ \mathrm{ml}$ concentration was 


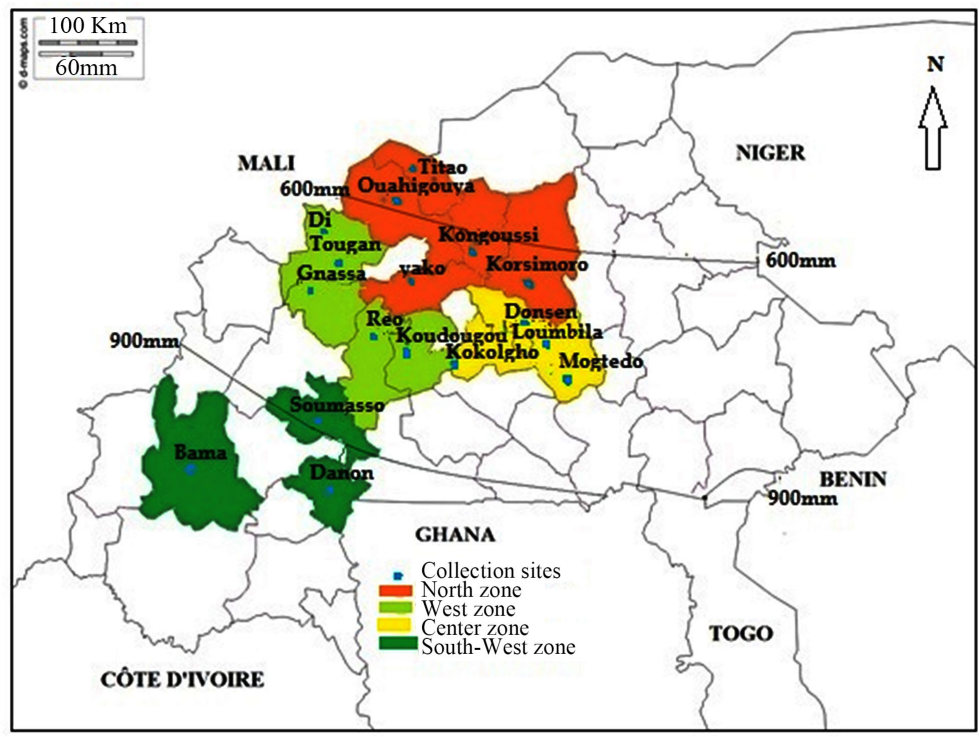

Figure 1. Onion production areas and Allium plant sample collection sites.

placed in each hole. The hole was then closed with a water-proof adhesive (scotch tape). The control bulbs were inoculated with sterile distilled water. After inoculation, the bulbs were placed in an incubation greenhouse at a temperature between $25^{\circ} \mathrm{C}$ and $28^{\circ} \mathrm{C}$ for 14 days. At the end of the incubation, each bulb was cut longitudinally into two parts and the length of rot in the tissue was measured. The degree of pathogenicity of each isolate was determined by measuring the extent of rot in millimeters on the infected bulbs. The study was conducted following a randomized complete block design consisting of 34 treatments (33 isolates + control) and 6 replications using one bulb per replication. An analysis of variance was performed on the percentages of seedling damping-off and bulb rot lengths caused by the different isolates using Statistical Analysis System (SAS) software, version 8; 2001.

\section{Results and Discussion}

\subsection{Results}

- Effect of Fusarium isolates on young onion plants

The results presented in Table 1 indicated that seed inoculation with isolates resulted in very significant decreases in onion seedling emergence rates $(\mathrm{p}=$ 0.0016). Except sterile distilled water used as a control, all isolates produced pre-emergence damping-off ranging from $4.17 \%$ to $62.50 \%$. The results also revealed significant variations between the combined percentages of pre-emergence and post-emergence damping-off $(\mathrm{p}=0.0044)$. However, no significant effects were noted on post-emergence damping-off ( $\mathrm{p}=0.4334)$. Analysis of pre-emergence damping-off data allowed isolates to be classified into seven different groups (Table 1). The first two groups consisting of six isolates, five of which belong to the species $F$. proliferatum (I21, I29, I31, I33, I37) and one to the species $F$. thapsinum (I35), induced strong pre-emergence damping-off 
$(>50 \%)$. The next three classes were composed of 20 isolates that caused moderate pre-emergence damping-off ranging from $20 \%$ to $50 \%$, and the last two groups with seven isolates, six of which belonged to the species $F$. oxysporum, caused relatively low pre-emergence damping-off ranging from $4.17 \%$ to $16.67 \%$.

Post-emergence damping-off ranging from $4.16 \%$ to $16.67 \%$ was also induced by the isolates (Table 1). Only six out of the 33 isolates (I5, I27, I31, I49, I52, I58) did not cause mortality on plants. However, the statistical analyses did not reveal any significant difference $(\mathrm{p}=0.4334)$ between the isolates themselves or between the isolates and the control for post-emergence damping-off.

By considering pre-emergence and post-emergence damping-off, statistical analysis allowed to classify the isolates into eight pathogenic groups (Table 1). Based on the rate of pre-emergence and post-emergence damping-off caused and on the basis of the grouping proposed by Sassaki [25], the isolates were divided into 3 classes (Table 2):

- The class of highly pathogenic isolates (HPAIs), including seven isolates that caused more than $50 \%$ of damping-off on seedlings. Of these isolates, five belong to the species $F$. proliferatum (I21, I29, I31, I33, I37), one to the species F. solani (I38) and one to the species F. thapsinum (I35).

- The class of moderately pathogenic (MP) isolates includes 22 isolates, 10 of which belong to $F$. proliferatum, nine to $F$. oxysporum, two to $F$. fujikuroi and one to $F$. solani, with seeding damping-off rates between $20 \%$ and $50 \%$.

- The class of low pathogenic isolates (PP) composed of 4 isolates all belonging to the species F. oxysporum, and the control (sterile distilled water), which caused percentages of seedling damping-off less than $20 \%$.

By grouping Fusarium isolates by species of membership, the analytical results (Table 3) revealed highly significant differences between Fusarium species with regard to pre-emergence and pre- and post-emergence damping-off. All the species studied generally caused significant damping-off on onion seedlings. $F$. thapsinum, represented by a single isolate, induced the highest rates of pre-emergence damping-off (54.17\%) which was statistically similar to those caused by $F$. solani, F. proliferatum and $F$. fujikuroi but strictly higher than those noted with $F$. oxysporum (22.44\%).

For post-emergence damping-off, plant mortality rates were statistically equal for all Fusarium species used and no difference was noted between these rates and that of the control (sterile distilled water) (Table 3).

Table 1. Percentages of pre-emergence, post-emergence damping-off and combined percentages of pre- and post-emergence damping-off recorded after inoculation of onion seeds with different Fusarium isolates.

\begin{tabular}{ccccc}
\hline Fusarium species & Insulation No. & $\begin{array}{c}\text { Pre-emergence } \\
\text { seeding cast } \\
\text { irons (\%) }\end{array}$ & $\begin{array}{c}\text { Post-emergence } \\
\text { seedling cast } \\
\text { irons (\%) }\end{array}$ & $\begin{array}{c}\text { Pre-emergence and } \\
\text { post-emergence } \\
\text { seeding wheels (\%) }\end{array}$ \\
\hline F. oxysporum & I5 & $4.17 \mathrm{de}$ & $0.00 \mathrm{a}$ & $4.17 \mathrm{e}$ \\
& I7 & $33.33 \mathrm{abcd}$ & $8.33 \mathrm{a}$ & $41.67 \mathrm{abcd}$ \\
\hline
\end{tabular}




\section{Continued}

\begin{tabular}{|c|c|c|c|c|}
\hline & I9 & $12.50 \mathrm{cde}$ & $12.50 \mathrm{a}$ & 25.00 bcde \\
\hline & $\mathrm{I} 16$ & $16.67 \mathrm{cde}$ & $16.67 \mathrm{a}$ & $33.33 \mathrm{abcde}$ \\
\hline & $\mathrm{I} 42$ & $12.50 \mathrm{cde}$ & $4.16 \mathrm{a}$ & $16.67 \mathrm{cde}$ \\
\hline & I 49 & $8.33 \mathrm{cde}$ & $0.00 \mathrm{a}$ & $8.33 \mathrm{de}$ \\
\hline & I50 & $37.50 \mathrm{abc}$ & $4.16 \mathrm{a}$ & $41.67 \mathrm{abcd}$ \\
\hline & $\mathrm{I} 52$ & $33.33 \mathrm{abc}$ & $0.00 \mathrm{a}$ & $33.33 \mathrm{abcd}$ \\
\hline & I58 & $20.83 \mathrm{bcde}$ & $0.00 \mathrm{a}$ & 20.83 bcde \\
\hline & I59 & $12.50 \mathrm{cde}$ & $4.16 \mathrm{a}$ & $16.67 \mathrm{cde}$ \\
\hline & I63 & $25.00 \mathrm{abcd}$ & $4.16 \mathrm{a}$ & 29.17 abcde \\
\hline & I66 & $37.50 \mathrm{abc}$ & $12.50 \mathrm{a}$ & $50.00 \mathrm{abc}$ \\
\hline & I67 & $37.50 \mathrm{abc}$ & $12.50 \mathrm{a}$ & $50.00 \mathrm{abc}$ \\
\hline \multirow[t]{15}{*}{ F. proliferatum } & I1 & 20.83 cbcde & $8.33 \mathrm{a}$ & 29.17 bcde \\
\hline & I3 & $4.17 \mathrm{de}$ & $16.67 \mathrm{a}$ & 20.83 bcde \\
\hline & I4 & $33.33 \mathrm{abc}$ & $4.16 \mathrm{a}$ & $37.50 \mathrm{abcd}$ \\
\hline & $\mathrm{I} 11$ & $37.50 \mathrm{abc}$ & $8.33 \mathrm{a}$ & $45.83 \mathrm{abcd}$ \\
\hline & $\mathrm{I} 14$ & 20.83 bcde & $8.33 \mathrm{a}$ & 29.17 bcde \\
\hline & I15 & $29.17 \mathrm{abcd}$ & $12.50 \mathrm{a}$ & $41.67 \mathrm{abcd}$ \\
\hline & $\mathrm{I} 17$ & $25.00 \mathrm{abcd}$ & $8.33 \mathrm{a}$ & $33.33 \mathrm{abcd}$ \\
\hline & $\mathrm{I} 18$ & $37.50 \mathrm{abc}$ & $4.16 \mathrm{a}$ & $41.67 \mathrm{abcd}$ \\
\hline & I19 & $37.50 \mathrm{abc}$ & 4. $16 \mathrm{a}$ & $41.67 \mathrm{abcd}$ \\
\hline & I 21 & $58.33 \mathrm{ab}$ & $4.16 \mathrm{a}$ & $62.50 \mathrm{ab}$ \\
\hline & I 29 & $58.33 \mathrm{ab}$ & $12.50 \mathrm{a}$ & $70.83 \mathrm{a}$ \\
\hline & $\mathrm{I} 31$ & $62.50 \mathrm{a}$ & $0.00 \mathrm{a}$ & $62.50 \mathrm{ab}$ \\
\hline & $\mathrm{I} 32$ & $20.83 \mathrm{abcd}$ & $8.33 \mathrm{a}$ & 29.17 abcde \\
\hline & $\mathrm{I} 33$ & $54.17 \mathrm{ab}$ & $8.33 \mathrm{a}$ & $62.50 \mathrm{ab}$ \\
\hline & $\mathrm{I} 37$ & $58.33 \mathrm{ab}$ & $4.16 \mathrm{a}$ & $62.50 \mathrm{ab}$ \\
\hline \multirow[t]{2}{*}{ F. solani } & $\mathrm{I} 24$ & $41.67 \mathrm{abc}$ & $8.33 \mathrm{a}$ & $50.00 \mathrm{abc}$ \\
\hline & $\mathrm{I} 38$ & $45.83 \mathrm{abc}$ & $16.67 \mathrm{a}$ & $62.50 \mathrm{ab}$ \\
\hline \multirow[t]{2}{*}{ F. fujikuroi } & $\mathrm{I} 2$ & $37.50 \mathrm{abc}$ & $8.33 \mathrm{a}$ & $25.83 \mathrm{abcd}$ \\
\hline & I 27 & $41.67 \mathrm{abc}$ & $0.00 \mathrm{a}$ & $41.67 \mathrm{abcd}$ \\
\hline F. thapsinum & $\mathrm{I} 35$ & $54.17 \mathrm{ab}$ & $4.16 \mathrm{a}$ & $58.33 \mathrm{abc}$ \\
\hline Witnesses & Water & $0.00 \mathrm{e}$ & $4.16 \mathrm{a}$ & $4.17 \mathrm{e}$ \\
\hline Average & & 31.49 & 6.86 & 38.35 \\
\hline $\mathrm{P}$ & & 0.0016 & 0.4334 & 0.0044 \\
\hline $\mathrm{CV}$ & & 33.36 & 62.08 & 28.94 \\
\hline
\end{tabular}

a The pre-emergence percentages of damping-off and the percentages of combined pre-emergence and post-emergence damping-off were transformed into Arc sinus before performing the analysis of variance in order to normalize the data and stabilize the variance over the entire data range. $b$ The values in the same column assigned with the same alphabetical letter(s) are not significantly different at the $5 \%$ threshold, according to the Duncan test. 
Table 2. Distribution of isolates according to their pathogenicity on seedlings.

\begin{tabular}{|c|c|c|c|c|}
\hline \multirow{2}{*}{$\begin{array}{l}\text { Fusarium } \\
\text { species }\end{array}$} & \multirow{2}{*}{ Isolates } & \multicolumn{3}{|c|}{$\begin{array}{l}\text { Classes defined according to the } \\
\text { level of pre-emergence and post-emergence fonts }\end{array}$} \\
\hline & & $\begin{array}{c}\mathrm{TP} \\
(>50 \% \text { of cast iron })\end{array}$ & $\begin{array}{c}\text { MP } \\
(20 \%-50 \% \text { of fonts })\end{array}$ & $\begin{array}{c}\text { PP } \\
(<20 \% \text { of fonts })\end{array}$ \\
\hline \multirow[t]{13}{*}{ F. oxysporum } & I5 & & & $\mathrm{X}$ \\
\hline & I7 & & $\mathrm{X}$ & \\
\hline & I9 & & $\mathrm{X}$ & \\
\hline & I16 & & $\mathrm{X}$ & \\
\hline & $\mathrm{I} 42$ & & & $\mathrm{X}$ \\
\hline & I 49 & & & $\mathrm{X}$ \\
\hline & I50 & & $\mathrm{X}$ & \\
\hline & I52 & & $\mathrm{X}$ & \\
\hline & I58 & & $\mathrm{X}$ & \\
\hline & I59 & & & $\mathrm{X}$ \\
\hline & I63 & & & $\mathrm{X}$ \\
\hline & I66 & & $\mathrm{X}$ & \\
\hline & I67 & & $\mathrm{X}$ & \\
\hline \multirow[t]{15}{*}{ F. proliferatum } & I1 & & $\mathrm{X}$ & \\
\hline & I3 & & $\mathrm{X}$ & \\
\hline & I4 & & $\mathrm{X}$ & \\
\hline & I11 & & $\mathrm{X}$ & \\
\hline & I14 & & $\mathrm{X}$ & \\
\hline & I15 & & $\mathrm{X}$ & \\
\hline & I17 & & $\mathrm{X}$ & \\
\hline & $\mathrm{I} 18$ & & $\mathrm{X}$ & \\
\hline & I19 & & $\mathrm{X}$ & \\
\hline & I 21 & $\mathrm{X}$ & & \\
\hline & I 29 & $\mathrm{X}$ & & \\
\hline & $\mathrm{I} 31$ & $\mathrm{X}$ & & \\
\hline & $\mathrm{I} 32$ & & $\mathrm{X}$ & \\
\hline & I33 & $\mathrm{X}$ & & \\
\hline & I37 & $\mathrm{X}$ & & \\
\hline \multirow[t]{2}{*}{ F. solani } & I 24 & & $\mathrm{X}$ & \\
\hline & $\mathrm{I} 38$ & $\mathrm{X}$ & & \\
\hline \multirow[t]{2}{*}{ F. fujikuroi } & I2 & & $\mathrm{X}$ & \\
\hline & I 27 & & $\mathrm{X}$ & \\
\hline F. thapsinum & I35 & $\mathrm{X}$ & & \\
\hline
\end{tabular}


Table 3. Importance of seedling damping-off (pre-, post- and pre- + post-emergence) caused by different Fusarium species on onion seedlings.

\begin{tabular}{ccccc}
$\begin{array}{c}\text { Fusarium } \\
\text { species }\end{array}$ & $\begin{array}{c}\text { Number of } \\
\text { isolates } \\
\text { evaluated }\end{array}$ & $\begin{array}{c}\text { Pre-emergence } \\
\text { damping-off } \\
(\%)\end{array}$ & $\begin{array}{c}\text { post-emergence } \\
\text { damping-off } \\
(\%)\end{array}$ & $\begin{array}{c}\text { Pre- and } \\
\text { post-emergence } \\
\text { damping-off }^{\mathrm{a}} \\
(\%)\end{array}$ \\
\hline $\begin{array}{c}\text { F. oxysporum } \\
\text { F. proliferatum }\end{array}$ & 13 & $(22.44) 26.36 \mathrm{~b}$ & $(6.09) 2.04 \mathrm{a}$ & $(28.53) 30.70 \mathrm{a}$ \\
F. solani & 2 & $(37.22) 36.21 \mathrm{ab}$ & $(7.50) 2.52 \mathrm{a}$ & $(44.72) 41.38 \mathrm{a}$ \\
$\begin{array}{c}\text { F. fujikuroi } \\
\text { F. thapsinum }\end{array}$ & 2 & $(43.75) 41.42 \mathrm{ab}$ & $(12.50) 3.21 \mathrm{a}$ & $(56.25) 48.65 \mathrm{a}$ \\
Witnesses & 1 & $(54.17) 47.65 \mathrm{a}$ & $(4.16) 1.84 \mathrm{a}$ & $(58.33) 50.12 \mathrm{a}$ \\
Average & & $(0.00) 0.82 \mathrm{c}$ & $(4.16) 1.84 \mathrm{a}$ & $(4.17) 8.39 \mathrm{~b}$ \\
P & & $(31.49)$ & $(6.86)$ & $(38.35)$ \\
CV & 0.0016 & 0.5742 & 0.0002 \\
\hline
\end{tabular}

a The percentages of pre-emergence damping-off and the percentages of combined pre- and post-emergence damping-off were transformed into Arc sinus before proceeding with the analysis of variance in order to normalize the data and stabilize the variance over the entire data range. $b$ The percentages of post-emergence damping-off were transformed into Square Root before proceeding with the analysis of variance in order to normalize the data and stabilize the variance over the entire data range. $c$ The values in brackets represent data expressed in percentages. $d$ The values of the same column assigned the same alphabetical letter(s) are not significantly $5 \%$ threshold, according to the Duncan test.

F. thapsinum and F. solani represented by one and two isolates, respectively, caused the highest rates of pre and post-emergence damping-off on seedlings (56.25\% - 58.33\%). However, statistical results revealed that the different Fusarium species caused the same rate on seedlings but that these rates were significantly higher $(28.53 \%-58.33 \%)$ than those recorded by the control treatment (4.17\%).

- Effect of Fusarium isolates on onion bulbs

Results of the pathogenicity assessment of isolates on bulbs revealed that inoculation of bulbs with Fusarium isolates resulted in internal rotting of bulbs with a length ranging from $0.83 \mathrm{~mm}$ to $25 \mathrm{~mm}$ with an average of $13.18 \mathrm{~mm}$. The results of the data analysis revealed a highly significant difference between isolates and allowed the isolates to be divided into 15 groups (Figure 2). Depending on the degree of pathogenicity (or extent of rot on the bulb), the isolates were classified into four groups: (Table 4).

The group of highly pathogenic isolates (TP), composed of seven isolates, three of which belong to the species $F$. proliferatum (I29, I4, I32), and four to $F$. oxysporum (I16, I50, I52, I66), which caused rots longer than $20 \mathrm{~mm}$ (Figure 2).

The group of moderately pathogenic isolates (MP) represented by 13 isolates including two belonging to F. oxysporum (I9, I58), nine to F. proliferatum (I1, I3, I14, I15, I17, I18, I21, I31, I37) one to F. fujikuroi (I27) and one to F. thapsinum (I35) with a rot length between 10 and $20 \mathrm{~mm}$. 
Table 4. Classification of isolates according to their degree of pathogenicity to bulbs.

\begin{tabular}{|c|c|c|c|c|c|}
\hline \multirow{2}{*}{$\begin{array}{l}\text { Fusarium } \\
\text { species }\end{array}$} & \multirow[b]{2}{*}{ Isolates } & \multicolumn{4}{|c|}{ Classes defined according to the extent of bulb rot } \\
\hline & & $\begin{array}{c}\mathrm{TP} \\
(\operatorname{rot}>20 \mathrm{~mm})\end{array}$ & $\begin{array}{c}\text { MP } \\
(10-20 \mathrm{~mm} \text { of rot })\end{array}$ & $\begin{array}{c}\mathrm{PP} \\
(2-10 \mathrm{~mm} \text { of rot })(<2\end{array}$ & $\begin{array}{c}\text { LOC } \\
\mathrm{mm} \text { of rot) }\end{array}$ \\
\hline \multirow[t]{13}{*}{ F. oxysporum } & I5 & & & & $\mathrm{X}$ \\
\hline & I7 & & & $\mathrm{X}$ & \\
\hline & I9 & & $\mathrm{X}$ & & \\
\hline & I16 & $\mathrm{X}$ & & & \\
\hline & $\mathrm{I} 42$ & & & $\mathrm{X}$ & \\
\hline & I 49 & & & $\mathrm{X}$ & \\
\hline & I50 & $\mathrm{X}$ & & & \\
\hline & I52 & $\mathrm{X}$ & & & \\
\hline & I58 & & $\mathrm{X}$ & & \\
\hline & I59 & & & & $\mathrm{X}$ \\
\hline & I63 & & & $\mathrm{X}$ & \\
\hline & I66 & $\mathrm{X}$ & & & \\
\hline & I67 & & & $\mathrm{X}$ & \\
\hline \multirow[t]{15}{*}{ F. proliferatum } & I1 & & $\mathrm{X}$ & & \\
\hline & I3 & & $\mathrm{X}$ & & \\
\hline & I4 & $\mathrm{X}$ & & & \\
\hline & I11 & & & $\mathrm{X}$ & \\
\hline & I14 & & $\mathrm{X}$ & & \\
\hline & I15 & & $\mathrm{X}$ & & \\
\hline & I17 & & $\mathrm{X}$ & & \\
\hline & $\mathrm{I} 18$ & & $\mathrm{X}$ & & \\
\hline & I19 & & & & $\mathrm{X}$ \\
\hline & I 21 & & $\mathrm{X}$ & & \\
\hline & I 29 & $\mathrm{X}$ & & & \\
\hline & $\mathrm{I} 31$ & & $\mathrm{X}$ & & \\
\hline & $\mathrm{I} 32$ & $\mathrm{X}$ & & & \\
\hline & $\mathrm{I} 33$ & & & $\mathrm{X}$ & \\
\hline & I37 & & $\mathrm{X}$ & & \\
\hline \multirow[t]{2}{*}{ F. solani } & I 24 & & & $\mathrm{X}$ & \\
\hline & I38 & & & $\mathrm{X}$ & \\
\hline \multirow[t]{2}{*}{ F. fujikuroi } & I 2 & & & $\mathrm{X}$ & \\
\hline & I27 & & $\mathrm{X}$ & & \\
\hline F. thapsinum & $\mathrm{I} 35$ & & $\mathrm{X}$ & & \\
\hline
\end{tabular}




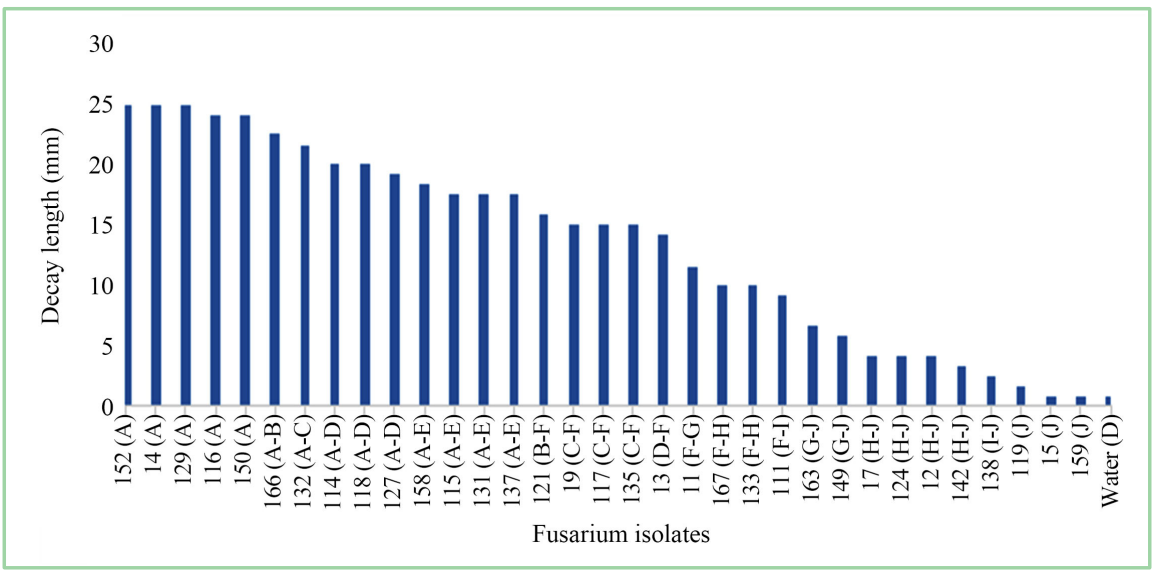

Figure 2. Extent of rot (in $\mathrm{mm}$ ) measured 14 days after inoculation of onion bulbs with 33 Fusarium isolates, in the presence of controls (sterile distilled water).

The group of low pathogenic isolates (PP) comprising ten isolates, five of which belong to $F$. oxysporum (I7, I42, I49, I63, I67), two to $F$. proliferatum (I11, I33), two to F. solani (I24, I38) and one to F. fujikuroi (I2) and which caused rots of lower lengths between 2 and $10 \mathrm{~mm}$.

The group of non-pathogenic isolates comprising three isolates including two of the species $F$. oxysporum (I19, I5) and one of $F$. proliferatum (I19) which caused rots of lengths statistically similar to that recorded by the control $(<2$ $\mathrm{mm})$.

Depending on the species of isolates, the estimated average rot lengths were between 3.33 and $16.10 \mathrm{~mm}$ and that observed with sterile distilled water was $0.83 \mathrm{~mm}$ (Figure 3). Statistical results revealed that the species $F$. proliferatum, $F$. thapsinum, F. oxysporum and F. fujikuroi were pathogenic on bulbs causing rots of significantly longer lengths $(11.66-16.10 \mathrm{~mm})$ than those caused by sterile distilled water $(0.83 \mathrm{~mm})$ (Figure 3$)$. Based on these results, $F$. solani was not pathogenic on bulbs because the length of the rot it caused $(3.33 \mathrm{~mm})$ was not control treatment $(0.83 \mathrm{~mm})$.

\subsection{Discussion}

Out of 33 Fusarium isolates used in the study, 29 isolates representing $87.87 \%$ of them were found pathogenic to young onion plants. These pathogenic isolates included seven highly pathogenic isolates causing more than $50 \%$ of damping-off on seedlings, and the other 22 moderately pathogenic isolates with $20 \%$ to $50 \%$ of damping-off rates. The action of isolates was more remarkable on pre-emergence damping-off with $20 \%-62.50 \%$ damping-off caused than on post-emergence damping-off with rates ranging from $4.17 \%$ to $16.67 \%$.

Among the isolates that caused damping-off on young plants, all 15 isolates belonging to $F$. proliferatum were identified as highly pathogenic for 5 isolates and moderately pathogenic for 10 isolates. These results indicated that the species $F$. proliferatum is strongly involved in pre-emergence and post-emergence damping-off of onions in Burkina Faso. For F. oxysporum, among the 13 isolates 


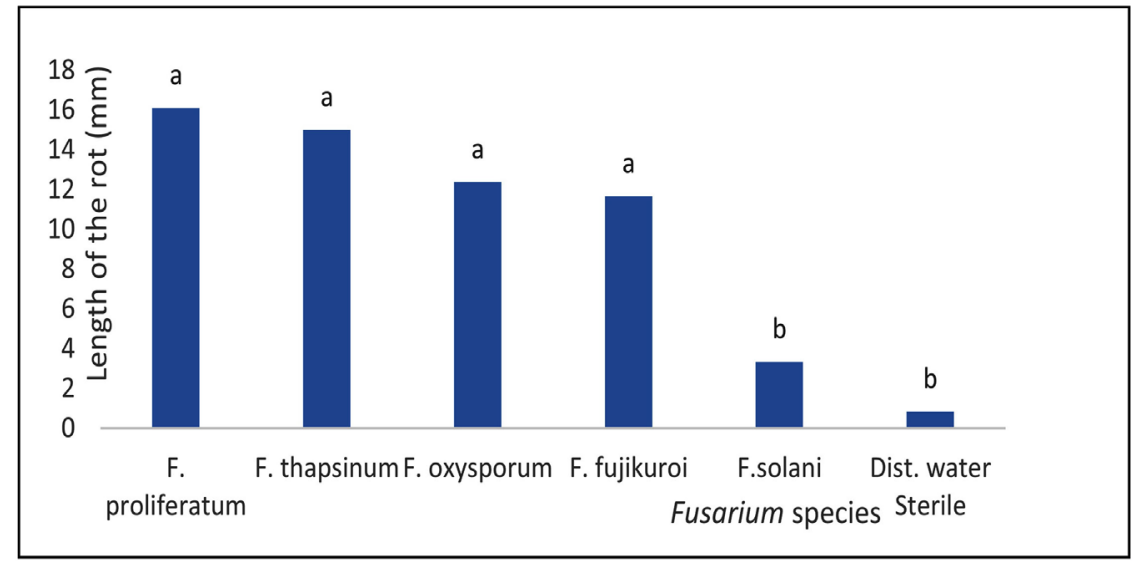

Figure 3. Mean lengths of rot induced 14 days after inoculation of onion bulbs by five Fusarium species, in the presence of controls (sterile distilled water).

tested, eight were moderately pathogenic, four were identified as low pathogenic and one (I5) was non-pathogenic on seedlings. From these results, F. oxysporum also appears to play an important role in onion seedling damping-off in Burkina Faso, however, with a relatively lower involvement compared to $F$. proliferatum.

The species $F$. solani, F. fujikuroi and $F$. thapsinum were poorly represented in the study with two, two and one isolates respectively, but all these isolates were pathogenic causing significant damage to young plants, which implies their effective involvement in onion seedling damping-off in Burkina Faso. Indeed, of the two isolates of $F$. solani used in the study, one was highly pathogenic and the other moderately pathogenic on young plants. The only one $F$. thapsinum isolate tested was highly pathogenic by causing sever damping-off, and both isolates of F. fujikuroi were moderately pathogenic. The results of this study showed that the Fusarium isolates responsible of damping-off on onion seedlings in Burkina Faso belong to F. proliferatum, F. solani, F. thapsinum, F. fujikuroi and F. oxysporum, with greater aggressive-ness of the $F$. proliferatum and $F$. thapsinum isolates.

Of the 33 isolates used in the study, 30 isolates representing $90.90 \%$, were pathogenic to bulbs. The isolates that caused the most significant rots (rotting length $>20 \mathrm{~mm}$ ) belong to the species $F$. oxysporum and $F$. proliferatum. All isolates of $F$. proliferatum species used in the study were identified as highly pathogenic (for 3 isolates), moderately pathogenic (9 isolates) and low pathogenic (2 isolates), except isolate I19 which was found to be non-pathogenic. Inoculation of seeds and onion bulbs with isolate I29 resulted in high rates of damping-off on seedlings and significant rotting on bulbs, reflecting the high virulence of this isolate on both seedlings and bulbs. These results also suggest a strong involvement of $F$. proliferatum in onion bulb rot in Burkina Faso.

For F. oxysporum, only two of the 13 isolates tested were found to be non-pathogenic on bulbs. Indeed, four isolates of the species were highly pathogenic, two moderately pathogenic, five low pathogenic and two non-pathogenic, including isolate 15 , which also did not cause damping-off on seedlings. Based 
on these results, the species $F$. oxysporum also appears to play an important role in onion bulb rot in Burkina Faso. Rushi, [27] had shown that F. oxysporum is a fungus that causes damage to several vegetable crops including onions. The only isolate of $F$. thapsinum used in the study caused 10 to $20 \mathrm{~mm}$ of rot on the bulbs, indicating its importance in this disease. On the other hand, the two isolates of the species $F$. solani were all low pathogenic on bulbs, thus showing the low involvement of this species in bulb rots. This result contrasts with that obtained by Dabiré [23] who identified F. solani as one of the major pathogens responsible for onion bulb rot in Burkina Faso. This suggests the existence of several strains of F. solani on onion in Burkina Faso. F. fujikuroi also showed moderate pathogenicity to bulb rot because of the two isolates tested, one was moderately pathogenic and the other low pathogenic. This study reports for the first time the pathogenicity of $F$. thapsinum, F. proliferatum and F. fujikuroi on seedlings and onion bulbs in Burkina Faso. Jeon et al. [28] noted a predominance of $F$. fujikuroi in rice seeds in Asia. They also demonstrated that this species reduced the germination of rice seeds and caused typical symptoms of balkanoe disease, leaf elongation and chlorosis on rice seeds or plants. $F$. thapsinum has previously been identified on sorghum seeds [29] [30]. According to Stokhom [30] F. thapsinum is one of the most common sorghum seed-borne ascomycetes in Burkina Faso. Pathogenicity tests carried out revealed that $F$. thapsinum caused strong growth inhibition in young plants with wilting symptoms on the leaves. Pedrozo and Little [31] also identified F. thapsinum on soybean seeds. Pathogenicity test results showed a reduction in emergence rates and increased mortality of young plants. Several other studies have previously been conducted on most Fusarium species worldwide [17] [23] [27] [32]. Indeed, the work of Stankovic [16] revealed that $F$. proliferatum was an important pathogen on onion and garlic $(A I-$ lium sativum) in Europe and that there was a potential risk of mycotoxin accumulation in contaminated plants of these two crops. F. proliferatum has also been found responsible for onion and garlic bulb rots in Argentina [33] and India [34]. The pathogenicity of F. oxysporum, F. proliferatum and F. solani on onions had also been reported by several authors [8] [16] [27]. In Iran, Ghanbarzadeh [8] identified $F$. oxysporum as the most virulent species on both young plants and onion bulbs, $F$. proliferatum as the most destructive on bulbs in storage. Similar to the results of this study, these same authors also recognized $F$. solani, responsible for pre and post-emergence damping-off on seedling but weakly involved in onion bulb rot.

Fusarium species live in the soil as chlamydospores and attack the basal parts of the on-ion in the field [35]. According to Özer and Köycü [36], the main source of implements can contribute to the spread of inoculum. Care should be taken during harvesting operations to avoid causing injury to bulbs as these injuries are routes of entry for the fungus. Fusarium species are associated with seeds. Adequate disinfection of the seeds before planting is necessary to effectively control the diseases they cause. 


\section{Conclusion}

The pathogenicity of the 33 isolates belonging to five Fusarium species (F. proliferatum, F. thapsinum, F. solani, F. oxysporum, and F. fujikuroi) tested, on Violet de Galmi variety, induced percentages of seedling damping-off ranging from $4.17 \%-70.83 \%$ with an average of $38.60 \%$, and lengths of internal bulb rot ranging from $0.83-25 \mathrm{~cm}$, with an average of $13.18 \mathrm{~cm}$. F. thapsinum (1) and $F$. proliferatum (15) isolates were the most pathogenic on both seedlings (15/15) and bulbs (13/15). The isolates of $F$. fujikuroi were moderately pathogenic on both seedlings and bulbs. All isolates of $F$. solani were only pathogenic on seedlings but very few on bulbs. F. oxysporum had a broad spectrum of aggressiveness consisting of isolates with high or low virulence, or even avirulence in all stages of plant development. Indeed, among the 13 isolates of $F$. oxysporum, eight were pathogenic on seedlings and four non-pathogenic. On the bulbs 11 over 13 isolates were pathogenic and two non-pathogenic. Screening of these different isolates over a wider range of onion varieties would confirm the pathogenicity of these isolates on onion and determine susceptible and resistant varieties. This knowledge is necessary for the development of appropriate and sustainable management methods against these diseases.

\section{Acknowledgements}

The authors would like to thank the Congregation of the Sisters of the Immaculate Conception of Ouagadougou (S.I.C.O) and the Institute of Environment and Agricultural Research (INERA) for their financial support for this work. They also thank the staff of the CREAF Phytopathology Laboratory for their efforts in setting up the trial. Many thanks to Dr. Joseph B. Batieno and Dr. Zakaria Dieni for improving the English version of the manuscript.

\section{Conflicts of Interest}

The authors declare no conflicts of interest regarding the publication of this paper.

\section{References}

[1] DPSAA (2011) Rapport d'analyse du module maraichage, bureau centrale de recen-sement général de l'Agriculture. Ministère de l'Agriculture de l'Hydraulique, et des res-sources halieutiques, Burkina Faso, 237 p.

[2] Assane, D.M. (2006) Les effets de la réappropriation de la culture du "Violet de Galmi", par les producteurs d'oignon de la région de TAHOUA-NIGER, sur la dynamique du territoire local, l'organisation sociale et économique. Thèse de doctorat, Développement rural. Université de Toulouse-Le Mirail, France, 281 p.

[3] Guissou, R., Cissé, K. and Pouya, T. (2012) Analyse des incitations et pénalisations pour l'oignon au Burkina Faso. Série notes techniques, SPAAA, FAO, Rome, 41 p.

[4] Faivre-Dupaigre, B., Baris, P. and Liagre, L. (2006) Etude sur la compétitivité des filières agricoles espace UEMOA (Elaboration d'un argumentaire de choix de filières). IRAM, $296 \mathrm{p}$. 
[5] Cramer, C.S., Mendoza, J.L. and Wall, M. (2002) 2000-2001 Onion Variety Trials at New Mexico State University. Agricultural Experiment Station·Research Report 748.

[6] Boukary, H. (2014) Caractérisation agro-morphologique et moléculaire des ecotypes locaux d'oignon (Allium cepa L.) du Niger. Thèse de Doctorat, Faculté des Sciences et Techniques, Université Abdou Moumouni de Niamey, Niamey, Niger, 106 p.

[7] Mc Callum, J. (2007) Onion. In: Kole, C., Ed., Genome Mapping and Molecular Breeding in Plants, Vegetables, Springer-Verlag, Berlin, Heidelberg, 332-347.

[8] Ghanbarzadeh, B., Goltapeh, E.M. and Safaie, N. (2014) Identification of Fusarium Species Causing Basal Rot of Onion in East Azarbaijan Province, Iran and Evaluation of Their Virulence on Onion Bulbs and Seedlings. Archives of Phytopathology and Plant Protection, 47, 1050-1062.

https://doi.org/10.1080/03235408.2013.829628

[9] CNUCED 2014 Rapport sur le commerce et le développement, 224 p.

[10] Dissanayake, C.M., Kashima, R., Tanaka, S. and Ito, S. (2009) Pathogenic Variation and Molecular Characterization of Fusarium Species Isolated from Wilted Welsh Onion in Japan. Journal of Genetic and Plant Pathology, 75, 37-45. https://doi.org/10.1007/s10327-008-0135-Z

[11] Lacy, M.L. and Lorbeer, W.J. (1995) Botrytis Leaf Blight. In: Schwartz, F.H. and Krishna, M., Eds., Compendium of Onion and Garlic Diseases, The American Phytopahological Society, APS Press, St. Paul, MN, 16-18.

[12] Schwartz, H.F. and Mohan, S.K. (2007) Compendium of Onion and Garlic Diseases and Pests. 2nd Edition, The American Phytopathological Society, St. Paul, MN, 136 p.

[13] Lager, S., (2011) Survey of Fusarium Species on Yellow Onion (Allium cepa) on Öland. Swedish (SLU), Swedish University of Agricultural Science, Uppsala.

[14] Brayford, D., (1996) IMI Descriptions of Fungi and Bacteria Set 127. Mycopathologia, 133, 35-36. https://doi.org/10.1007/BF00437097

[15] Southwood, M.J. (2012) Evolution and Detection of Fusarium oxysporum f. sp. Cepae in Onion in South Africa. Ph.D. Dissertation, Stellenbosch University, Stellenbosch.

[16] Stankovic, S., Levic, J., Petrovic, T., Logrieco, A. and Moretti, A. (2007) Patho-Genicity and Mycotoxin Production n by Fusarium proliferatum Isolated from Onion and Garlic in Serbia. European Journal of Plant Pathology, 118, 165-172. https://doi.org/10.1007/s10658-007-9126-8

[17] Zlata, K.S., Jelena, L., Stevan, M., Jelica, G.V., Mirjana, V. and Svjetlana, A. (2008) Fusarium Rot of Onion and Possible Use of Bioproduct. Zbornik Matice Srpske za Prirodne Nauke, 114, 135-148. https://doi.org/10.2298/ZMSPN0814135K

[18] Eltariki, F.E.M., Tiwari, K., Ariffin, I.A. and Alhoot, M.A. (2018) Genetic Diversity of Fungi Producing Mycotoxins in Stored Crops. Journal of Pure and Applied Microbiology, 12, 1815-1823. https://doi.org/10.22207/JPAM.12.4.15

[19] Caligiore, P., Gei, F.P., Valdez, J.G., Piccolo, R.J. and Galmarini, C.R. (2014) Influence of Fusarium spp. Isolate and Inoculum Density on Resistance Screening Tests in Onion. Tropical Plant Pathology, 39, 19-27. https://doi.org/10.1590/S1982-56762014005000005

[20] Madhavi, M. and Kavitha, V.M. (2012) Studies on Alternaria porri (Ellis) Ciferri Pathogenic to Onion (Allium cepa L.). Archives of Applied Science Re-Search, 4, $1-9$.

[21] Ouedraogo, L. and Rouamba, A. (1997) Identification de deux bactéries 
res-ponsables de la pourriture des bulbes d'oignon en stockage au Burkina Faso. Annales de I Université de Ouagadougou, Série B, 5, 198-204.

[22] Tarpaga, W.V. (2012) Contribution à l'étude de la montaison prématurée des variétés tropicales d'oignon (Allium cepa L.): Cas du Violet de Galmi, cultivé au Nord du Burkina Faso. Thèse de Doctorat, Université de Ouagadougou, Burkina Faso, $120 \mathrm{p}$.

[23] Dabiré, T.G. (2017) Diagnostic, caractérisation des maladies fongiques de l'oignon (Allium cepa L.) dans les agrosystèmes maraîchers du Burkina. Thèse de Doctorat en Sciences Agronomiques et Ingénierie Biologique. Université catholique de Louvain, Belgique, $256 \mathrm{p}$.

[24] Kintega, K.R., Zida, P.E., Tarpaga, V.W., Sankara, P. and Sereme, P. (2019) Identification of Fusarium Species Associated with Onion (Allium cepa) Plants in the Field in Burkina Faso (In Press).

[25] Sasaki, K., Takahara, K., Tanaka, S., Shigyo, M. and Ito, S. (2015) Genetic and Pathogenic Variability of Fusarium oxysporum f. sp. Cepae Isolated from Onion and Welsh Onion in Japan. Phytopathology, 105, 525-532. https://doi.org/10.1094/PHYTO-06-14-0164-R

[26] Bayraktar, H. and Dolar, F.S. (2011) Molecular Identification and Genetic Diversity of Fusarium Species Associated with Onion Fields in Turkey. Journal of Phytopathology, 159, 28-34. https://doi.org/10.1111/j.1439-0434.2010.01715.x

[27] Rushi, S. (2012) Pathogenicity of Aspergillus Niger in plants. Cibtech Journal of Microbiology, 1, 47-51.

[28] Jeon, H.Y. and Lee, H. (2013) Depletion of Aurora-A in Zebrafish Causes Growth Retardation Due to Mitotic Delay and p53-Dependent Cell Death. The FEBS Journal, 280, 1518-1530. https://doi.org/10.1111/febs.12153

[29] Levic, J.T., Stankovic, S.Z., Krnjaja, V.S. and Bocarov-stancic, A.S. (2009) Fusarium Species: The Occurrence and the Importance in Agriculture of SERBIA. Zbornik Matice srpske za prirodne nauke, 116, 33-48. https://doi.org/10.2298/ZMSPN0916033L

[30] Stokholm, M.S., Wulff, E.G., Zida, E.P., Thio, I.G., Néya, J.B., Soalla, R.W., Lund, O.S., et al. (2016) DNA Barcoding and Isolation of Vertically Transmitted Ascomycetes in Sorghum from Burkina Faso: Epicoccum sorghinum Is Dominant in Seedlings and Appears as a Common Root Pathogen. Microbiological Research, 191, 38-50. https://doi.org/10.1016/j.micres.2016.05.004

[31] Pedrozo, R. and Little, C.R. (2014) First Report of Seedborne Fusarium thapsinum and Its Pathogenicity on Soybean (Glycine max) in the United States. Plant Disease, 98, 1745. https://doi.org/10.1094/PDIS-08-14-0806-PDN

[32] Daniel, P., Cara, M., Nosir, W., Gálvez, L., Cruz, A., Woodward, S., González-Jaén, M.T. and Tello, J.C. (2012) Fusarium proliferatum Isolated from Garlic in Spain: Identification, Toxigenic Potential and Pathogenicity on Related Allium Species. Phytopathologia Mediterranea, 51, 207-218.

[33] Salvalaggio, A.E. and Ridao, A.C. (2013) First Report of Fusarium proliferatum Causing Rot on Garlic and Onion in Argentina. The American Phytopathological Society, 97, 556. https://doi.org/10.1094/PDIS-05-12-0507-PDN

[34] Ravi, S.N., Nagalakshmi, D.M. and Bagyanarayana, G. (2014) First Report of Fusarium proliferatum Causing Rot of Onion Bulbs (Allium cepa L.) in India. Science, Technology and Arts Research Journal, 3, 1-3. https://doi.org/10.4314/star.v3i2.1

[35] Schwartz, H.F. and Mohan, K.S. (2008) Basal Rot of Onion. In: Schwartz, F.H. and 
Mohan Krishna, S., Eds., Compendium of Onion and Garlic Diseases, 2è Edition, The American Phytopahological Society, APS Press, St. Paul, MN.

[36] Özer, N. and Köycü, N.D. (2004) Seed-Borne Fungal Diseases of Onion and Their Control. In: Mukerji, K.G., Ed., Disease Management of Fruits and Vegetables, Kluwer Academic Publishers, Dordrecht, 281-306.

https://doi.org/10.1007/0-306-48575-3_8 